\title{
Peter Beltram
}

\section{NOVOSTI, KI JIH JE VPELJALA V LETU 2013 SPREJETA RESOLUCIJA O NACIONALNEM PROGRAMU IZOBRAŽEVANJA ODRASLIH ZA OBDOBJE 2013-2020 (RENPIO 2013-2020)}

Nekoliko neopazno je šla mimo novost, ki jo je vpeljal novi ReNPIO 2013-2020 (2013), sprejet v državnem zboru 24. oktobra 2013. Ta pomembni dokument opredeljuje prednostne naloge, programe, podporne dejavnosti, ciljne skupine, instrumente za spremljanje in obseg javnih financ, ki jih država namenja izobraževanju odraslih. Prejšnji ReNPIO, ki je veljal v obdobju 2005-2010, je vključeval le dve ministrstvi, sicer najbolj pomembni za področje izobraževanja odraslih, ministrstvo za izobraževanje, znanost in šport (MIZŠ) ter ministrstvo za delo, družino, socialne zadeve in enake možnosti (MDDSZ), kar je bila njegova pomanjkljivost. Zato je novi ReNPIO zajel tudi druge resorje, ki v okviru svojih področij izvajajo dejavnosti in/ali programe, namenjene obveščanju, ozaveščanju, prosvetljevanju ali izobraževanju različnih ciljnih skupin odraslih, kar je vse mogoče obravnavati kot izobraževanje v širšem pomenu.

Paleta dejavnosti in programov, ki so zdaj združeni pod enim dežnikom, je zelo raznovrstna in obsežna. Tradicionalnim programom, namenjenim spodbujanju splošnega izobraževanja, dvigu izobrazbene ravni in pridobivanju temeljnih zmožnosti, so se pridružili: a) obveščanje in dvig zavesti o zdravstvenih tveganjih škodljivih navad in vedenja, ki ga v okviru različnih akcij izvaja ministrstvo za zdravje, b) izobraževanje in svetovanje državljanom, ki se nepoklicno ukvarjajo s kmetijskimi dejavnostmi, kako se odzivati na vremenske razmere ali na delovanje škodljivcev (ministrstvo za kmetijstvo), c) krepitev zavesti o podnebnih spremembah in spodbujanje ustreznega vedenja v vsakdanjem življenju (ločevanje odpadkov, recikliranje, smotrna poraba vode in drugo), ki jih izvaja ministrstvo za okolje, d) kulturno prosvetljevanje s krepitvijo zavesti o narodovi kulturni dediščini in spodbujanje čim širšega kroga prebivalcev, da prevzamejo aktivno vlogo pri njenem ohranjanju in razvoju (ministrstvo za kulturo), in še veliko več.

Uresničitev zamisli o vključitvi toliko različnih programov v ReNPIO pa je prinesla številne nove izzive na različnih ravneh procesov upravljanja in odločanja: na področju načrtovanja, regulacije, merjenja, spremljanja in vrednotenja. 
Na primer: vsi učitelji, mentorji, svetovalci in drugi profili strokovnih delavcev, ki sodelujejo pri izvajanju javno financiranih izobraževalnih programov za odrasle, morajo opraviti pedagoško-andragoško usposabljanje. Pri izvajanju tako širokega spektra programov, kot jih vključuje novi ReNPIO, bo od izvajalcev izpolnjevanje takega pogoja težko pričakovati. Vendar pa bi bilo za izboljšanje kakovosti in dometa teh različnih programov smiselno uvesti nekatere instrumente, ki bi ponudnike spodbujali k dvigu ravni njihovih kompetenc na področju učnih pristopov in metod, primernih za različne ciljne skupine odraslih.

$\mathrm{V}$ zadnjih desetih letih spremljanje in vrednotenje rezultatov javno financiranih izobraževalnih programov za odrasle, ki jih izvajajo različni izvajalci, tako javni zavodi kot zasebniki, zajema številne vidike in vrste meritev z uporabo različnih instrumentov. Programi, umeščeni v 1. prednostno področje (splošno, neformalno izobraževanje), so vrednoteni glede na uspešnost privabljanja pripadnikov ranljivih ciljnih skupin (brezposelni, manj izobraženi, osipniki in drugi); uspešnost 2. prednostnega področja (dvig izobrazbene ravni) je bila merjena s številom odraslih, vpisanih $\mathrm{v}$ formalno izobraževanje, in njihovo uspešnostjo; uspešnost programov usposabljanja, povezanega z delovnim mestom (3. prednostno področje), pa se je ocenjevala po številu prehodov iz statusa nezaposlenosti v zaposlitev in ohranjanju ogroženih delovnih mest.

Različne vrste programov, ki ji zajema novi ReNPIO, pa zahtevajo nove pristope pri oblikovanju ustreznih merilnih orodij. Odločili smo se, da te programe razvrstimo glede na temeljne zmožnosti, krepitvi katerih so namenjeni. Pri tem si pomagamo s spiskom osmih temeljnih zmožnosti (ključnih kompetenc), ki so na področju vseživljenjskega učenja opredeljene na ravni EU (1. komunikacija v maternem jeziku, 2. komunikacija v tujih jezikih, 3. številska predstavljivost in kompetence v matematiki, naravoslovju in tehnologiji, 4. digitalna pismenost, 5 . učenje učenja, 6 . socialne in državljanske kompetence, 7 . inovativnost in podjetnost, 8. kulturna zavest in izražanje), ki smo jim dodali še deveto s skupnim imenom »poklicna usposobljenost«, ki vključuje različne spretnosti in kompetence, namenjene dvigu zaposljivosti.

Kljub tem spremembam, ki jih uvajamo pri spremljanju uresničevanja ReNPIO, nameravamo glavni poudarek pri vrednotenju doseženega ohraniti na uspešnosti pri privabljanju ranljivih skupin, da se vključijo v izobraževalne dejavnosti. Na Andragoškem centru Slovenije še vedno verjamemo, da je glavna vloga javnega financiranja izobraževanja odraslih, poleg omogočanja formalnega izobraževanja, spodbujanje splošnega, neformalnega izobraževanja, ki je podlaga za razvoj drugih dveh področij vseživljenjskega učenja, formalnega izobraževanja in $\mathrm{z}$ delom povezanega usposabljanja. To je tudi razlog, da je razvrstitev prednostnih področjih ostala enaka tudi v novem ReNPIO.

\section{LITERATURA}

Resolucija o nacionalnem programu izobraževanja odraslih za obdobje 2013-2020 (2013). Pridobljeno s https://www.uradni-list.si/files/RS_-2013-090-03262-OB P001-0000.PDF\#!/pdf. 